\title{
An analysis of interorganizational relationships in health/fitness clubs: some aspects of organizational interdependence
}

\author{
Shuji Yamashita ${ }^{1}$, Osamu Yamagata ${ }^{2}$, Shinichi Demura ${ }^{3}$, Hiroshi Naka $^{4}$ and Fumio Gohshi ${ }^{5}$
}

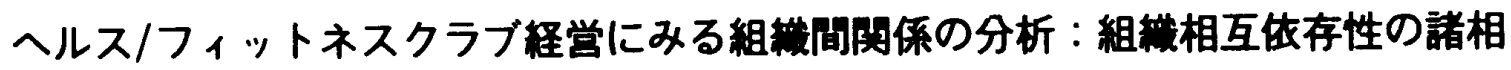
山下 秋二11 山形 修2) 出村 慎一3) 中 比呂志4) 郷司 文男5)

抄録

本研究は，ヘルス/フィットネスクラフの経営に従亭する組織単位間の相互依存性の研究である. これらクラブ経営体は，各々自己の関与する組織間网係システムにおいて，互いに役割モデルして

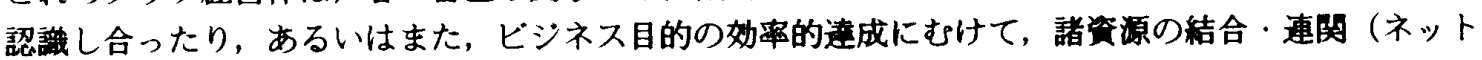

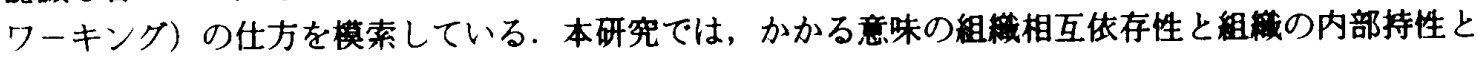
の関係を分析した。謂査データは，現在の我が国で展開されているヘルス/フィットネスクラフの上 級管理職(支配人)から求めた。データ源となったクラブはいすれれ多種目福合型の運動施設であり，

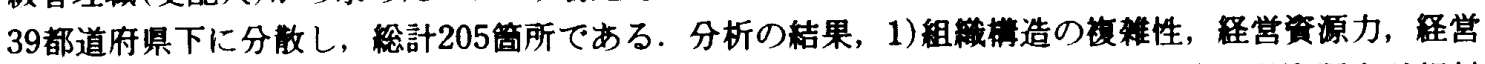
資源独自性の高さがクラプ間における役割モテルとしての期待を高めること，2)経営資源力が相対

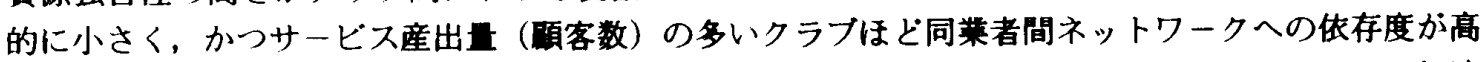
くなること，3)異莱種（とくに一般サービス莱及び同連スボーツ施設への）依存は，市場への伝達 情報量，施設サービ入革新の数，サービス産出目の多さ，及び市场情埌の信頼性のなさなどが影副す ること，そして4)ネットワーキングの実際上の形態は，そのブロセスからみて計画的なむのと創発

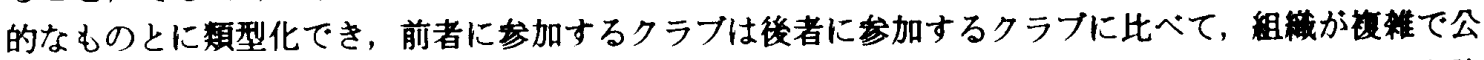

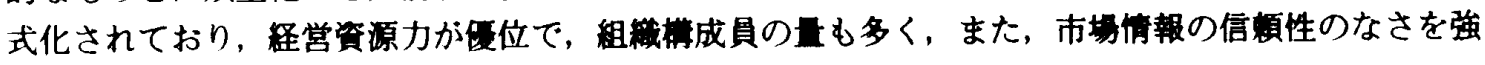
く感じていること,などが明かとなった。

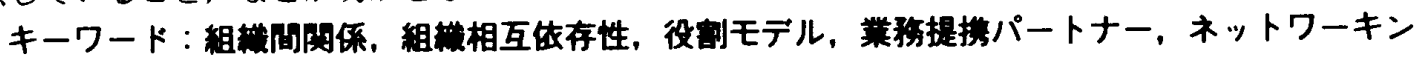
グ

(Japan J. Phys. Educ. 40: 1-13, May, 1995)

\section{Introduction}

Key words: interorganizational relationships, organizational interdependence, role model, business tie partners, networking

1）京都教育大学 干612 京都府京都市伏見区潹草藤森町 1

2）大阪成畹女子短期大学 干533 大阪府大阪市東定川区相川3-10-62

3）金沢大学教育学部 干920 石川県金次市角間

4) 福井工莱高等専門学校 干916 福井県籍江市下司町

5）宮城学院女子短期大学 干981 宮城県仙台市青葉区桜ケ丘9-1-1
1. Kyoto University of Education, 1 Fukakusa-Fujinomori-cho, Fushimi-ku, Kyoto-shi, Kyoto (612)

2. Osaka-Seikei Women's Junior College, 3-10-62 Aikawa, Higashiyodogawa-ku, Osaka-shi, Osaka (533)

3. Kanazawa University, Faculty of Education, Kadoma, Kanazawa-shi, Ishikawa (920)

4. Fukui National College of Technology, Geshi-cho, Sabae-shi, Fukui (916)

5. Miyagi-Gakuin Women's Junior College, 9-1-1 Sakuragaoka, Aoba-ku, Sendai-shi, Miyagi (981) 
the 9 years from 1982 to 1990 , as noted by Oga and Kimura ${ }^{14)}$, the health/fitness club sector, where sales soared to 14.3 times, was especially remarkable. In these circumstances every health/ fitness club faces a wide range of interorganizational relationships. They perceive each other not only as a competitor but as a role model for their business. Furthermore each club may be interlocking resources and consulting mutual interests through the networking.

The major purpose of this paper is to explore some of the causes and consequences of organizational interdependence among health/fitness clubs. One aspect of organizational interdependence that is examined here is the degree to which club business organization is perceived as a role model by other organizations in the same line of business. The other aspect is the nature of interorganizational networks on which club business organization is dependent. In particular, we are interested in relating these aspects of the club business organization's relationships with other organizations to internal organizational behavior of the club (organizational characteristics and perceived diversity in market).

Thus this paper explores one aspect of the general field of interorganizational analysis. In the past, two approaches to the study of interorganizational relationships have emerged. There are those on the one hand, who view interorganizational relationships from an exchange perspective (Levine and White ${ }^{11)}$, Tuite $^{21)}$, White ${ }^{24)}$ ). According to this approach, relations form when members of two or more organizations perceive mutual benefits or gains from interacting. Others, however, have adopted a power-dependency approach to interorganizational relations (Blau), Emerson $^{6)}$, Pfeffer and Salancik ${ }^{16)}$ ). Here, it is implied that the motivation to interact is asymmetrical. The interorganizational relationship only forms when the motivated party is powerful enough to force or induce the other to interact.

Organizations differ in the degree to which their decisions and actions are affected by other organizations. This variable was termed "system connectedness" by Emery and Trist ${ }^{7)}$ or "external accountability" by Rogers and Rogers ${ }^{17)}$, but we prefer to call the concept organizational interdependence, the degree to which an organization is dependent on, or responsive to, other organizations.

Most studies of organizational interdependence essentially conceive of the organization as an entity that needs inputs and provides outputs, linking together a number of organizations via the mechanisms of exchanges or transactions (Levine and White $^{11)}$, Levine et al. ${ }^{12)}$, Thompson ${ }^{20)}$ ). Little is known about such aspects of the sport organizations, although interorganizational analysis has been pushed forward in sport management studies (Stern ${ }^{18)}$, Yatsushiro et al. $\left.{ }^{26)}\right)$. Certainly, it is not easy to describe the facts of exchanges at the interorganizational level. Some types of organizational exchanges involve the sharing of clients, funds, and staff in order to perform activities for some common objective (Levine and White ${ }^{11)}$ ).

We gave prominence to the information exchanges, and hence assumed that a core organization (with a higher degree of role model than any other organization) would be existing in the organizational set (as being comprised of all organizations pursuing a similar goal). That is, according to Rogers and Rogers ${ }^{17)}$, organizations, like individuals, may have "reference groups." It might be thought, of course, that each of the health/fitness clubs has an organization which it consistently takes into consideration in its actions and decision making.

In the next step for gaining a clear conception of organizational interdependence, we assumed that those clubs would form an interorganizational network in order to facilitate their business. Ac- 
cording to Teramoto's typology on the interorganizational networks ${ }^{19)}$, it is suggested that the nature of club business networks must be examined in two research questions: (1) what type of industry is the "business tie partners" (partner organizations) to each club?; (2) what process does each club go through to interlock business ties?

\section{Hypotheses}

The following specific hypotheses are tested in this research:

$\mathrm{H}_{1}=$ The degree of role model varies with the organizational characteristics (i.e., organizational innovation, organizational structure, resources, and size).

$\mathrm{H}_{2}=$ The type of business tie partners varies with the organizational characteristics (i.e., organizational innovation, resources, and size), and the perceived diversity in market.

$\mathrm{H}_{3}=$ The process for interlocking business ties varies with the organizational characteristics (i.e., organizational innovation, organizational structure, resources, and size), and the perceived diversity in market.

Following some researchers, at least three types of interdependence can be distinguished: (1) horizontal interdependence, (2) vertical interdependence, and (3) diagonal interdependence (Astley and Fombrun ${ }^{2)}$, Fombrun and Astley8), Pennings ${ }^{15)}$ ). Horizontal interdependence exists when all members of an organizational set compete with each other in obtaining similar resources and disposing of similar goods and services. Vertical interdependence exists between symbiotically related firms linked by sequential work flows. Diagonal interdependence exists between firms located in different but interrelated industrial sectors.
The first hypothesis is derived from the horizontal interdependence and argues that the organizational characteristics will be a good predictor of the degree of role model in the organizational set. Competitive firms enhance observational modeling each other and gain valuable market information and technical know-how by learning their competitors' activities. In the circumstances, as a matter of course, it is supposed that the health/fitness club which is being learned by other clubs has internal organizational diversity (diversity of organizational structure). It stimulates organizational innovation. Organizational innovation increases the need for resources or size. Therefore, we have hypothesized $\mathrm{H}_{1}$.

The second hypothesis is derived from the vertical and diagonal interdependence, and also derived from a power-dependency framework of interorganizational relations in that it considers factors affecting the dependence of resources between the organizations in the relationship. The organizations seek a partner in order to keep the balance of power in the organizational set. Organizational power is fundamentally supported by means of resources and size. Organizational innovation pervades new combination of resources not only in the same line of business but also in different industrial sectors. In addition, the life cycles of particular managerial innovations in organizations are tied to and affected by many factors in their environments (diversity in market). Thus we have hypothesized $\mathrm{H}_{2}$.

The third hypothesis suggests that linkage between an organization and another is not always provided as planned. Organizations can complement each other in the rendering of services to individual clients by means of interlocking informal business ties spontaneously. Whether interorganizational networks are formed intentionally or spontaneously is depend upon the degree of organizational innovation, internal organizational 
diversity, resources, size, and the perception of diversity in market. Thus we have hypothesized $\mathrm{H}_{3}$.

\section{Methodology}

\section{Data collection}

The findings are based on a sample of 205 clubs, which has been carried on business as a facility for multiple sport sctivities, located dispersively in 39 urban and rural prefectures of Japan. The sample was $68.3 \%$ of all the subjects of investigation ( 300 clubs selected at random).

The data were collected by administering a questionnaire comprising items representing the operational definitions of the variables. All the data were collected in 1991 . There was no way to determine how adequately these data truly represented the entire organization's behavior with regard to an organizational interdependence, because this research collected these data only from the chief executive (as called a club manager) of each organization in the sample of clubs.

\section{The measurement of organizational inter- dependence}

There are many possible measures of an organizational interdependence. One, used by Aiken and Hage ${ }^{1)}$, is the number of joint programs conducted cooperatively with other organizations. Of course it is a fine method, but the issues raised in this paper can not be discussed well enough by it. We view the organizational interdependence in two aspects: the degree of role model and the nature of interorganizational networks with a focal organization. These were then measured or classified for this research in the following manner.

The degree to which club business organization was perceived as a role model by other organizations was measured by asking club managers a series of self-report questions, again using Likerttype scales. It was thought that the club had been perceived as a role model by other clubs when the manager recognized his own club as follows: (1) people who is starting a club business come here to seek advice, (2) staff of other clubs come here to inspect, (3) mass media or trade magazines play up here, and (4) other clubs imitate here. The response categories varied along a five-point scale of: (1) never, (2) seldom, (3) occasionally, (4) fairly often and (5) always.

The nature of interorganizational networks is determined by the industrial difference between a focal organization and organization tied with it. Therefore, to begin with, business tie partners were classified into two large types: (1) the homogeneous professions and (2) the heterogeneous professions. The latter was grouped again into three classes: (1) allied sport facility (such as golf club, tennis club, and swim club), (2) health resort (such as health spa, Kurhaus, and recreation park), and (3) general service industry (such as hotel, department store, and beauty parlor). The degree to which each of the health/ fitness clubs was dependent on those respective professions was measured by five-point Likert scales focused on the following managemental problems: (1) program development, (2) information exchange, (3) earning power, (4) the will to work, and (5) social prestige.

Subsequently, interorganizational networks were classified into two types according to the process for interlocking business ties: (1) planned networking (intentionally or formally interlocked) and (2) emergent networking (spontaneously or informally interlocked).

\section{The measurement of organizational char- acteristics}

The organizational characteristics comprise four variables: organizational innovation, or- 
reliability of information and the short time span of feedback are indexes of the uncertainty.

The above-mentioned four dimensions of market diversity are all defined here in terms of the perception of club business organization members. The club managers received a questionnaire measuring the four dimensions used in this research. Each questionnaire had four or five items. The respective managers indicated their responses to the items on five-point scales anchored at the extremes with polar adjectives. The following items and their response formats are the representatives.

(1) The production and marketing operations of your club are geographically... (very concentrated 12345 very widely dispersed). (2) The promotional strategy your club utilizes is generally... (very limited 12345 very diverse). (3) The markets that you serve are generally... (not competitive $\begin{array}{lllll}1 & 2 & 3 & 4 & 5\end{array}$ very competitive and hostile). (4) In the markets that you serve, the frequency of unpredictable changes in demand is... (very low 12345 very high).

\section{Treatment}

Principal component analysis was applied to the variables with the plural questionnaire items in order to examine the extent to which each item would be valid as a indicator of the variable. And the only first principal component scores were used in the subsequent analyses of the data. The statistical techniques employed, specially in order to test the hypotheses, were multiple regression analysis, canonical correlation analysis, and discriminant analysis.

In this paper correlations or differences which fell below .05 level of significance were considered to be substantively meaningful.

\section{Findings}

\section{Organizational characteristics of a model club}

Table 1 depicts the organizational characteristics of a model club. There are significant relationships between the degree to which club business organization is perceived as a role model by other organizations and organizational characteristics, excluding centralization only. The relationship between the resources power and the degree of role model is very high $(r=.497)$. It is followed by the resources uniqueness $(r=.448)$ and the complexity $(r=.382)$.

The resulting generalizations somewhat oversimplify reality, of course, by treating each of the above independent variables separately in its relationship to the degree of role model. It may not be reasonable to expect any one independent variable to be highly related to the degree of role model, nor to assume that orgaizational characteristics considered in this research are independently related to a model club. Many of the independ-

Table 1 Relationships between the degree of role model and organizational characteristics

\begin{tabular}{lc}
\hline $\begin{array}{c}\text { Organizational } \\
\text { characteristics }\end{array}$ & $\begin{array}{c}\text { Pearsonian product-moment } \\
\text { correlation coefficients } \\
\text { between each organizational } \\
\text { characteristic and the } \\
\text { degree of role model }\end{array}$ \\
\hline $\begin{array}{l}\text { Number of new sport } \\
\text { programs }\end{array}$ & $.220^{* *}$ \\
$\begin{array}{l}\text { Number of new facility } \\
\text { services }\end{array}$ & $.196^{* *}$ \\
Complexity & $.382^{* * *}$ \\
Centralization & .142 \\
Formalization & $.323^{* * *}$ \\
Resources power & $.497^{* * *}$ \\
Resources uniqueness & $.448^{* * *}$ \\
Number of personnel & $.345^{* * *}$ \\
Number of clients & $.332^{* * *}$ \\
\hline$* *$ Significant at the .01 level & \\
$* * *$ Significant at the .001 level &
\end{tabular}


ent variables are interrelated with each other, as well as with the degree of role model. Accordingly the next step we must do is to report the findings of the multiple regression analysis for the sample. Statistical techniques like multiple correlation allow us to determine how much of the variance in dependent variable is uniquely explained by its covariance with a independent variable, while removing the covariance of both dependent variable and the independent variable with all other independent variables. Substantial proportion explained by the independent variable can be examined also by its partial correlation coefficient with dependent variable.

Table 2 indicates that a substantial proportion of the variance was explained by the nine independent variables acting simultaneously. In summary, for the sample $37.6 \%$ of the variance in the degree of role model was accounted for by the complexity (partial $r=.235$ ), The resources power (partial $\mathrm{r}=.225$ ), and the resources uniqueness (partial $r=.182$ ). The other factors did not make a significant contribution to the explained variance of the dependent variable.

\section{Types of partner organizations: depend- ence on the homogeneous or heterogeneous profession}

This section reports the relationships between the type of external organization selected as an interlock tie partner in making club business networks and internal organizational behavior of the club. The internal organizational behavior includes organizational characteristics and perceived diversity in market. Complexity, centralization and formalization, however, were excluded here from the organizational characteristics, because it was assumed that they were indexes of the intra-organizational structure and would not be influential in selecting the type of business tie partners.

Correlation between each variable and the degree of dependence on the other organizations can be found in Table 3 . The correlation

Table 2 Multiple regression analysis of the degree of role model by nine independent variables

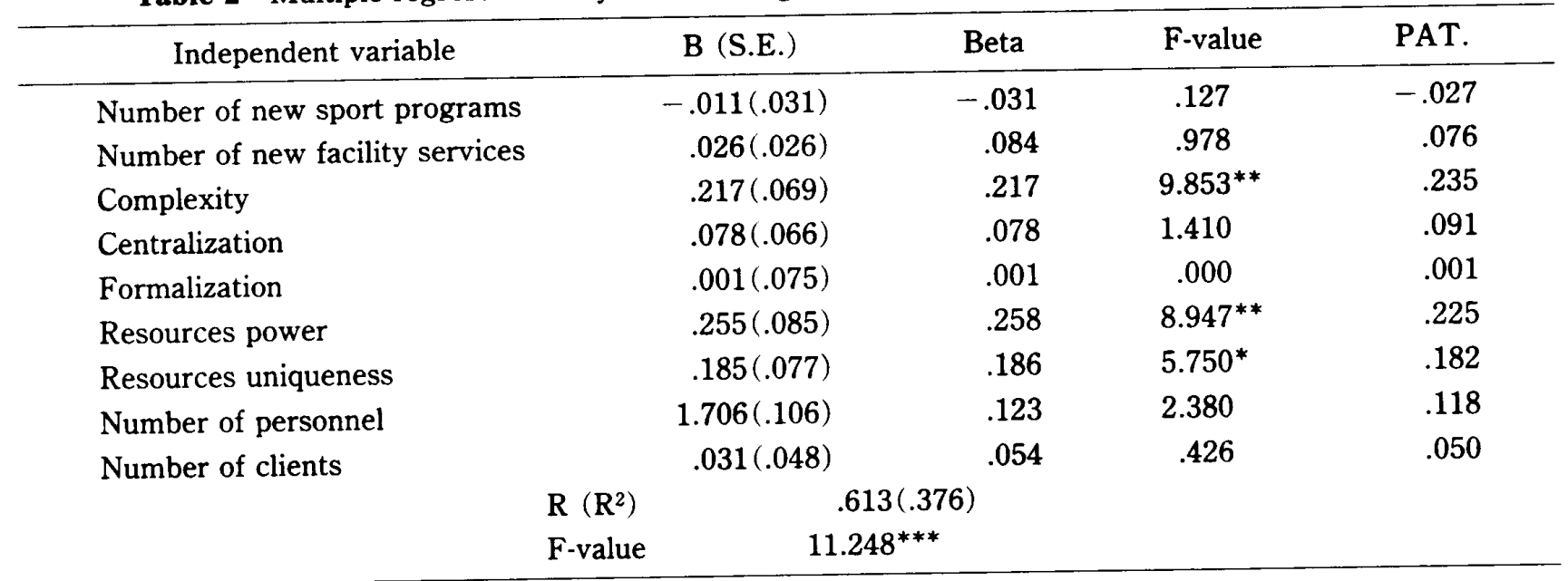

$B=$ Nonstandardized regression coefficients $($ S.E. $=$ Standard error of $B)$

Beta $=$ Standardized regression coefficients

PAT.$=$ Partial correlation coefficients

$\mathrm{R}=$ Multiple correlation coefficient $\left(\mathrm{R}^{2}=\right.$ Coefficient of determination $)$

* Significant at the .05 level

** Significant at the .01 level

*** Significant at the .001 level 
Table 3 Correlation coefficients between degree of dependence on the other organizations and organizational characteristics or perceived diversity in market

\begin{tabular}{|c|c|c|c|c|}
\hline & \multirow{2}{*}{$\begin{array}{l}\text { Degree of } \\
\text { dependence on the } \\
\text { homogeneous } \\
\text { profession network }\end{array}$} & \multicolumn{3}{|c|}{$\begin{array}{c}\text { Degree of dependence on the heterogeneous } \\
\text { profession }\end{array}$} \\
\hline & & $\begin{array}{l}\text { Allied sport } \\
\text { facility }\end{array}$ & Health resort & $\begin{array}{l}\text { General service } \\
\text { industry }\end{array}$ \\
\hline \multicolumn{5}{|l|}{ Organizational characteristics } \\
\hline Number of new sport programs & -.013 & .132 & .023 & .070 \\
\hline Number of new facility services & .047 & $.145^{*}$ & .060 & $.147^{*}$ \\
\hline Resources power & -.084 & .071 & .082 & $.149^{*}$ \\
\hline Resources uniqueness & -.054 & .074 & .104 & $.176^{*}$ \\
\hline Number of personnel & .050 & $.154^{*}$ & $.154^{*}$ & $.154^{*}$ \\
\hline Number of clients & $.146^{*}$ & $.187^{* *}$ & $.194^{* *}$ & $.191^{* *}$ \\
\hline \multicolumn{5}{|l|}{ Perceived diversity in market } \\
\hline Number of sources of information & .108 & .119 & .135 & $.160^{*}$ \\
\hline Quantity of information transmitted & $.195^{* *}$ & $.248^{* * *}$ & $.268^{* * *}$ & $.265^{* * *}$ \\
\hline Lack of reliability of information & $.194^{* *}$ & $.231^{* *}$ & $.192^{* *}$ & .133 \\
\hline Short time span of feedback & -.038 & -.077 & .004 & -.119 \\
\hline
\end{tabular}

* Significant at the .05 level

** Significant at the .01 level

*** Significant at the .001 level

coefficients between selected ten independent variables and the dependent variable, degree of dependence on the homogeneous profession network, are shown in the left edge of the columns. The number of clients $(r=.146)$, the quantity of information transmitted $(r=.195)$ and the lack of reliability of information $(r=.194)$ were significantly related to the dependent variable. The following are the relationships to the heterogeneous profession.

There were significant correlations between the degree of dependence on the allied sport facility and number of new facility services $(r=.145)$ as well as number of personnel $(r=.154)$, number of clients $(r=.187)$, quantity of information transmitted $(r=.248)$, and lack of reliability of information $(\mathrm{r}=.231)$. There were significant relationships between the degree of dependence on the health resort and number of personnel $(r=.154)$ as well as number of clients $(r=.194)$, quantity of information transmitted $(r=.268)$, and lack of reliability of information $(r=.192)$. And further, there were significant relationships between the degree of dependence on the general service industry and number of new facility services $(r=.147)$ as well as resources power $(r=.149)$, resources uniqueness $(r=.176)$, number of personnel $(r=.154)$, number of clients $(r=.191)$, number of sources of information $(r=.160)$, and quantity of information transmitted $(r=.265)$.

Table 4 shows the findings of the multiple regression analysis of the degree of dependence on the homogeneous profession network by ten independent variables. $12.7 \%$ of the variance in the degree of dependence on the homogeneous profession was explained by such independent variables as resources power and number of clients.

While there was no relationship between resources power and the degree of dependence on the homogeneous profession (see Table 3 ), it could be recognized in Table 4 that there was rela- 
Table 4 Multiple regression analysis of the degree of dependence on the homogeneous profession network by ten independent variables

\begin{tabular}{lcccr}
\hline \multicolumn{1}{c}{ Independent variable } & B (S.E.) & Beta & F-value & PAT. \\
\hline Number of new sport programs & $-.024(.037)$ & -.066 & .408 & -.049 \\
Number of new facility services & $.036(.031)$ & .118 & 1.350 & .090 \\
Resources power & $-.229(.100)$ & -.230 & $5.231^{*}$ & -.174 \\
Resources uniqueness & $-.042(.094)$ & -.042 & .196 & -.034 \\
Number of personnel & $-1.807(1.387)$ & -.129 & 1.698 & -.100 \\
Number of clients & $.150(.060)$ & .258 & $6.339^{*}$ & .191 \\
Number of sources of information & $.062(.081)$ & .062 & .580 & .059 \\
Quantity of information transmitted & $.154(.079)$ & .153 & 3.806 & .149 \\
Lack of reliability of information & $.132(.080)$ & .132 & 2.723 & .127 \\
Short time span of feedback & $-.162(.087)$ & -.162 & 3.465 & -.143 \\
& $\mathrm{R}\left(\mathrm{R}^{2}\right)$ & $.357(.127)$ & & \\
& F-value & $2.439^{* *}$ & & \\
\hline
\end{tabular}

$B=$ Nonstandardized regression coefficients $($ S.E. $=$ Standard error of $B)$

Beta $=$ Standardized regression coefficients

PAT.$=$ Partial correlation coefficients

$\mathbf{R}=$ Multiple correlation coefficient $\left(\mathbf{R}^{2}=\right.$ Coefficient of determination $)$

* Significant at the .05 level

** Significant at the .01 level

tively strong negative correlation between this variable and the degree of dependence on the homogeneous profession (partial $\mathrm{r}=-.174$ ). When the relationship between number of clients and the degree of dependence on the homogeneous profession is similarly controlled for each of the ten independent variables separately, the relationship between these two variables remains relatively strong (partial $r=.191$ ). Quantity of information transmitted and lack of reliability of information, while significantly related to the degree of dependence on the homogeneous profession when considered singly (see Table 3 ), are not substantially related to the degree of dependence on the homogeneous profession when considered in combination with other variables.

With regard to the dependence on the heterogeneous profession, it has three indexes, i.e., degree of dependence on allied sport facility, health resort, or general service industry. Accordingly it should be given weight to each of those variables also. Table 5 depicts the canonical correlation between three dependent variables and ten independent variables. The weightings which appear on this table suggests that the dependence on the heterogeneous profession is likely to be associated with the degree of dependence on general service industry $(w=.596)$, the degree of dependence on allied sport facility $(w=.580)$, the quantity of information transmitted $w=.579$ ), the number of new facility services $(w=.501)$, the number of clients $(w=.383)$, and the lack of reliability of information $(w=.353)$.

The significance of canonical correlation coefficient is reported in terms of Wilks' lambda statistic and chi-square value $\left(\lambda=.766, \mathrm{x}^{2}=\right.$ 45.532).

\section{Planned networking and emergent net- working}

The health/fitness clubs could select which to participate in planned networking or emergent 
Table 5 Canonical correlation between three dependent variables and ten independent variables in dependence on the heterogeneous profession

\begin{tabular}{lclr}
\hline \multicolumn{1}{c}{ Dependent variables } & Weight & \multicolumn{1}{c}{ Independent variables } & Weight \\
\hline $\begin{array}{l}\text { Degree of dependence on } \\
\text { allied sport facility }\end{array}$ & .580 & Number of new sport programs & -.118 \\
$\begin{array}{l}\text { Degree of dependence on } \\
\text { health resort }\end{array}$ & -.009 & Number of new facility services & .501 \\
$\begin{array}{l}\text { Degree of dependence on } \\
\text { general service industry }\end{array}$ & .596 & Resources power & -.182 \\
& & Number of personnel & .216 \\
& Number of clients & -.064 \\
& Number of sources of information & .383 \\
& Quantity of information transmitted & .033 \\
& Lack of reliability of information & .579 \\
& Short time span of feedback & -.353 \\
Canonical correlation coefficient & .411 \\
Eigenvalue & .169 \\
Wilks' lambda & .766 \\
Chi-square value & $45.532^{*}$ \\
\hline
\end{tabular}

* Significant at the .05 level

networking if they would interlock business ties with other organizations. On the basis of these processes, the sample was classified as planned networking group (146 clubs) and emergent networking group (11 clubs). The former were those clubs which had been interlocking business ties with a specified organization, intentionally, from the beginning. The latter were those clubs which had been interlocking business ties no more than by a spontaneous chance. In this paper, discriminant analysis was employed to determine whether the two groups were different in internal organizational behaviors (including organizational structure).

As shown in Table 6, on five of the variables there is a significant difference between the planned networking group and the emergent networking group. That is, complexity, formalization, resources power, number of personnel, and lack of reliability of information were statistically significant beyond the .05 level.

The discriminative power of total battery of variables, as well as the discriminative power of individual variables, is reported in terms of rate of discrimination. The rate of discrimination by total battery of variables was $76.5 \%$. Regarding the rate of discrimination by a given variable, it can be seen from the right edge of this table. The highest rate was the resources power $(66.6 \%)$. Likewise, such organizational structure indexes as complexity $(66.1 \%)$ and formalization $(66.2 \%)$ had more influence on the discriminative power.

\section{Conclusions and Implications}

In summary, the present investigation permits four conclusions: first, club business organizations, which are perceived as a role model by other organizations in the same line of business, are more complex organizations and have higher power and uniqueness in their resources; second, the more the club business organization estimates the amount of service production (number of clients), and in contrast with this, the lower it estimates its own resources power, the more it is likely to be dependent on the homogeneous profession network; third, a high degree of dependence 
Table 6 Discrimination between planned networking group and emergent networking group ${ }^{\dagger}$

\begin{tabular}{|c|c|c|c|c|c|}
\hline \multirow[b]{2}{*}{ Variable } & \multicolumn{2}{|c|}{ Mean value of each group } & \multirow{2}{*}{ t-value } & \multirow{2}{*}{$\begin{array}{l}\text { Discriminant } \\
\text { coefficient }\end{array}$} & \multirow{2}{*}{$\begin{array}{l}\text { Rate of } \\
\text { discrimination by } \\
\text { a given variable }\end{array}$} \\
\hline & $\begin{array}{l}\text { Planned } \\
(\mathrm{N}=146)\end{array}$ & $\begin{array}{c}\text { Emergent } \\
(\mathrm{N}=11)\end{array}$ & & & \\
\hline Number of new sport programs & 3.226 & 2.636 & 1.414 & .042 & $57.4 \%$ \\
\hline Number of new facility services & 2.892 & 3.091 & .246 & -.102 & 51.5 \\
\hline Complexity & .089 & -.760 & $2.662^{* *}$ & .546 & 66.1 \\
\hline Centralization & .033 & -.321 & 1.149 & .160 & 57.1 \\
\hline Formalization & .147 & -.659 & $2.675^{* *}$ & .361 & 66.2 \\
\hline Resources power & .103 & -.771 & $2.746^{* *}$ & .757 & 66.6 \\
\hline Resources uniqueness & .069 & -.472 & 1.702 & .001 & 60.0 \\
\hline Number of personnel & 53.000 & 28.000 & $2.830^{* *}$ & .125 & 60.1 \\
\hline Number of clients & 2477.000 & 1781.000 & 1.476 & -.042 & 59.1 \\
\hline Number of sources of information & .054 & -.015 & .216 & -.165 & 51.4 \\
\hline Quantity of information transmitted & .081 & -.040 & .386 & -.453 & 52.4 \\
\hline Lack of reliability of information & .101 & -.657 & $2.407^{*}$ & .866 & 64.7 \\
\hline Short time span of feedback & -.030 & .379 & 1.306 & -.022 & 58.1 \\
\hline \multicolumn{4}{|c|}{ Rate of discrimination by total battery of variables } & $76.5 \%$ & \\
\hline
\end{tabular}

+ In this table, those clubs had never participated practically in networking were removed.

* Significant at the .05 level

** Significant at the .01 level

on the heterogeneous profession (specifically the general service industry and the allied sport facility) will occur when the club has to transmit much information to the market, increases a number of new facility services, produces a large amount of service, and perceives lack of reliability of information in the market; and fourth, the investigation suggests that the practical forms of networking can be classified in terms of the process for interlocking business ties with other organizations and those clubs that had participated in planned networking, were more likely to have complex and formalized organization, hold a dominant position in terms of the facet of resources power, have a large number of personnel and perceive lack of reliability of information in the market, than those participated in emergent networking.

The first result was consistent with the hypothesis $\left(\mathrm{H}_{1}\right)$ that the degree of role model varies with the organizational characteristics, espe- cially in organizational structure and resources. The parts relating to organizational innovation and size, however, were not supported enough. The second and third results were consistent with the hypothesis $\left(\mathrm{H}_{2}\right)$ that the type of business tie partners varies with the organizational characteristics and the perceived diversity in market. Hypothesis $\left(\mathrm{H}_{3}\right)$, which concerned with the process for interlocking business ties was warranted by the final result. Organizational innovation itself seemed not much to affect this process, however.

The data presented here suggest that organizational interdependence among health/fitness clubs poses various and implicative problems for the sport management studies. Except in the Hypothesis $\left(\mathrm{H}_{3}\right)$, where we were interested in whether interorganizational networks were formed intentionally or spontaneously, we have been concerned almost exclusively with the flow of influence from organization to organization. 
We have brought up again and again two basic sorts of questions.

First of all we have been asking, "What are the characteristics of core organizations in sport market?" The mechanism by which organizational interdependence is translated into new organizational behavior involves the organizational learning, which come from the modeling a core organization's behavior. A study by Walker ${ }^{22}$ ) suggests that innovations can diffuse from organization to organization through interorganizational networks, in a paralleled process to that among individuals in a social system. If organizations can have opinion leadership, as individuals do, it can be said that our data on the Hypothesis $\left(\mathrm{H}_{1}\right)$ suggest the profiles of opinion leader in the organizational set.

And secondly we have been saking, "What organization is linked to what organization in networks?" Walker ${ }^{23)}$ gathered sociometric data to determine the actual patterns of opinion leadership and diffusion networks among the American states. It was shown in that study that state administrators communicated most readily with their counterparts in states that they believed had similar resources, social problems, and administrative styles. A conceptual label "homophily" was assigned to this phenomenon by Lazarsfeld and Merton ${ }^{10)}$, in case of interpersonal networks.

We have dealt with this problem as the degree of dependence on the homogeneous profession network and suggested that a number of clients and resources power often constituted the contingency variables. Part of our data on the hypothesis $\left(\mathrm{H}_{2}\right)$ tells about it. There is little doubt that the homophily in case of interorganizational networks involves not only horizontal interdependence but also vertical interdependence. No organization is likely to engage in only information exchange relationships with other organizations. Organization, more or less, engages in power-de- pendency relationships.

Further we have dealt with the problem of dependence on the heterogeneous profession, that is, diagonal interdependence. It is no longer the problem of the flow of influence. This pattern of interdependence exceedingly characterizes today's interorganizational networks. The implications in our data are vast and difficult to assess but will certainly affect such important outcomes as the new type of business tie partners, the network innovation, and the quality and range of services available to consumers in sport market.

This paper only provides a starting point for setting up guidelines for the study of interorganizational relationships in sport management. Perhaps future research should emphasize more careful separation of sport organization and business organization.

(Part of this paper was read at the Annual Convention of Japanese Society of Management for Physical Education and Sports, Osaka, March 29, 1994.)

\section{References}

1) Aiken, M. and Hage, J. (1968) Organizational interdependence and intra-organizational structure. American Sociological Review 33: 912-930.

2) Astley, W. G. and Fombrun, C. J. (1983) Technological innovation and industrial structure: the case of telecommunications. Advances in Strategic Management 1: 205-229.

3) Becker, S. W. and Whisler, T. L. (1967) The innovative organization: a selective view of current theory and research. Journal of Business 40: 462469.

4) Blau, P. M. (1964) Exchange and power in social life. John Wiley \& Sons: New York.

5) Duncan, R. B. (1976) The ambidextrous organization: designing dual structure for innovation. In: Kilman, R. H. et al. (Eds.) The management of organization design, Vol. 1. North-Holland: New York, pp. 167-188.

6) Emerson, R. M. (1967) Power-dependence relations. American Sociological Review 27: 31-41. 
7) Emery, F. E. and Trist, E. L. (1965) The causal texture of organizational environments. Human Relations 18: 21-32.

8) Fombrun, C. J. and Astley, W. G. (1982) The telecommunications community: an institutional overview. Journal of Communication 32: 56-68.

9) Hage, J. and Aiken, M. (1970) Social change in complex organizations. Random House: New York.

10) Lazarsfeld, P. F. and Merton, R. K. (1964) Friendship as social process: a substantive and methodological analysis. In: Berger, $M$. et al. (Eds.) Freedom and control in modern society. Octagon: New York, p. 23.

11) Levine, S. and White, P. E. (1961) Exchange as a conceptual framework for the study of interorganizational relationships. Administrative Science Quarterly 5: 583 601.

12) Levine, S., White, P. E. and Paul, B. D. (1963) Community interorganizational problems in providing medical care and social services. American Journal of Public Health 53: 1183-1195.

13) Nonaka, I. (1974) Organization and market. Chikurashobo: Tokyo. 〈in Japanese : 野中郁次郎, 組市場〉。

14) Oga, J. and Kimura, K. (1993) Recent trends in the sports industry in Japan. Journal of Sport Management 7: 249-255.

15) Pennings, J. M. (1981) Strategically interdependent organizations. In: Nystrom, P. and Starbuck, W. (Eds.) Handbook of organizational design 2. Oxford University Press: Oxford, pp. 433-455.

16) Pfeffer, J. and Salancik, G. R. (1978) The external control of organizations. Harper \& Row: New York.

17) Rogers, E. M. and Rogers, R. A. (1976) Communication in organizations. Free Press: New York, pp. 160-161.

18) Stern, R. N. (1979) The development of an interor- ganizational control network: the case of intercollegiate athletics. Administrative Science Quarterly 24: 242-266.

19) Teramoto, Y. (1987) Interorganizational network. In: Nonaka, I and Teramoto, Y. (Eds.) Business administration. Chuokeizaisha: Tokyo, pp. 205-230. 〈in Japanese：寺本義也，組織間ネットワーク〉.

20) Thompson, J. D. (1962) Organizations and output transactions. American Journal of Sociology 68: 309-324.

21) Tuite, M. F. (1972) Toward a theory of joint decision-making. In: Tuite, M. F., Chisholm, R. and Radnor, M. (Eds.) Interorganizational decision making. Aldine: Chicago, pp. 9-19.

22) Walker, J. L. (1966) The diffusion of innovations among the American States. American Political Science Review 63: 880-899.

23) Walker, J. L. (1971) Innovation in state politics. In: Jacob, H. and Vines, K. N. (Eds.) Politics in the American states: a comparative analysis. Brown: Boston, p. 381.

24) White, P. E. (1974) Intra- and interorganizational studies. Administration and Society 6: 105-152.

25) Wilson, J. Q. (1966) Innovation in organization: notes toward a theory. In: Thompson, J. D. (Ed.) Approaches to organizational design. University Press: Pittsburgh, pp. 193-218.

26) Yatsushiro, T., Yanagisawa, K. and Shimizu, N. (1993) Toward for a conceptual framework for the study of interorganizational relationships in community sport. Bulletin of Institute of Health and Sport Sciences, University of Tsukuba 16:1-9. 〈in Japanese：八代 勉はか，地城スポーツの释営を めぐる組闇関係の研究〉.

平成 6 年 2 月 25 日受付 平成 7 年 3 月 18 日受理 